Western University

Scholarship@Western

Aboriginal Policy Research Consortium International (APRCi)

2004

Characteristics of Aboriginal Injecting Drug Users in Sydney, Australia: Prison History, Hepatitis C Status and Drug Treatment Experiences

Carolyn Day

Joanne Ross

Kate Dolan

Follow this and additional works at: https://ir.lib.uwo.ca/aprci

Part of the Criminology and Criminal Justice Commons, Other Public Health Commons, and the Substance Abuse and Addiction Commons

Citation of this paper:

Day, Carolyn; Ross, Joanne; and Dolan, Kate, "Characteristics of Aboriginal Injecting Drug Users in Sydney, Australia: Prison History, Hepatitis C Status and Drug Treatment Experiences" (2004). Aboriginal Policy Research Consortium International (APRCi). 408.

https://ir.lib.uwo.ca/aprci/408 
This article was downloaded by: [University of Western Ontario]

On: 25 October 2012, At: 13: 14

Publisher: Routledge

Informa Ltd Registered in England and Wales Registered Number: 1072954

Registered office: Mortimer House, 37-41 Mortimer Street, London W1T 3J H, UK

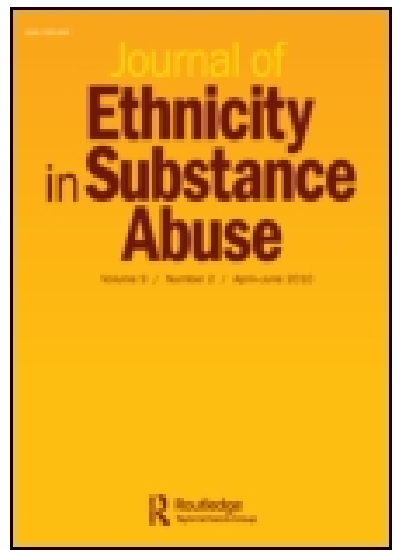

\section{J ournal of Ethnicity in Substance Abuse}

Publication details, including instructions for authors and subscription information:

http:// www. tandfonline.com/loi/ wesa20

\section{Characteristics of Aboriginal Injecting Drug Users in Sydney, Australia: Prison History, Hepatitis C Status and Drug Treatment Experiences}

Carolyn Day Bsc (Hons) ${ }^{a}$, J oanne Ross $\mathrm{PhD}^{\mathrm{a}}$ \& Kate Dolan $\mathrm{PhD}^{\mathrm{a}}$

${ }^{a}$ National Drug and Alcohol Research Centre, University of New South Wales, Australia

Version of record first published: 04 Oct 2008.

To cite this article: Carolyn Day Bsc (Hons), J oanne Ross PhD \& Kate Dolan PhD (2004): Characteristics of Aboriginal Injecting Drug Users in Sydney, Australia: Prison History, Hepatitis C Status and Drug Treatment Experiences, J ournal of Ethnicity in Substance Abuse, 2:3, 51-58

To link to this article: http:// dx. doi.org/ 10.1300/J233v02n03_03

\section{PLEASE SCROLL DOWN FOR ARTICLE}

Full terms and conditions of use: http://www.tandfonline.com/page/termsand-conditions

This article may be used for research, teaching, and private study purposes. Any substantial or systematic reproduction, redistribution, reselling, loan, sub-licensing, systematic supply, or distribution in any form to anyone is expressly forbidden. 
The publisher does not give any warranty express or implied or make any representation that the contents will be complete or accurate or up to date. The accuracy of any instructions, formulae, and drug doses should be independently verified with primary sources. The publisher shall not be liable for any loss, actions, claims, proceedings, demand, or costs or damages whatsoever or howsoever caused arising directly or indirectly in connection with or arising out of the use of this material. 


\title{
Characteristics of Aboriginal Injecting Drug Users in Sydney, Australia: Prison History, Hepatitis C Status and Drug Treatment Experiences
}

\author{
Carolyn Day, Bsc (Hons) \\ Joanne Ross, $\mathrm{PhD}$ \\ Kate Dolan, PhD
}

\begin{abstract}
Australian Aboriginals are overrepresented in prisons and tend to be overrepresented in studies of injecting drug users (IDU). The aim of this study was to examine differences between Aboriginal and non-Aboriginal IDUs in terms of gender, prison history and hepatitis $\mathrm{C}$ status and testing. Secondary analyses were conducted on data from three cross-sectional studies of IDUs. These studies employed similar methodologies, with recruitment being through needle and syringe programs, methadone clinics, snowballing and street intercepts. All studies were coordinated through the National Drug and Alcohol Research Centre. Aboriginal people were overrepresented in all studies, were more likely to have been incarcerated and to report heroin as their drug of choice than non-Aboriginal IDUs. Females tended to be overrepresented
\end{abstract}

Carolyn Day, Joanne Ross and Kate Dolan are all affiliated with the National Drug and Alcohol Research Centre, University of New South Wales, Australia.

Address correspondence to: Carolyn Day, National Drug and Alcohol Research Centre, University of New South Wales, NSW Australia 2052 (E-mail: carolyn.day@ unsw.edu.au).

The authors wish to acknowledge APET and ABRIDUS coordinators Paul Deitze and Robyn Dwyer of Turning Point Alcohol and Drug Inc., Melbourne. They also thank Associate Professor Shane Darke of NDARC for providing access to IDRS data.

Journal of Ethnicity in Substance Abuse, Vol. 2(3) 2003

http://www.haworthpress.com/store/product.asp?sku=J233

(C) 2003 by The Haworth Press, Inc. All rights reserved. 
among Aboriginal IDUs, were more likely to have been incarcerated and had a longer period of time since their last hepatitis $\mathrm{C}$ test than non- $\mathrm{Ab}$ original female IDUs. Aboriginal people are overrepresented among IDUs in Sydney. Given their greater risk of incarceration, particularly among females, Aboriginal IDUs were at greater risk of hepatitis $\mathrm{C} \mathrm{ex-}$ posure than non-Aboriginal IDUs. The prison setting provides an opportunity to promote drug treatment and hepatitis $\mathrm{C}$ testing, though more needs to be done to reduce drug use and incarceration. [Article copies available for a fee from The Haworth Document Delivery Service: 1-800HAWORTH. E-mail address: <docdelivery@haworthpress.com> Website: <http:// www.HaworthPress.com> () 2003 by The Haworth Press, Inc. All rights reserved.]

KEYWORDS. Australian Aboriginals, injecting drug use, prison, drug treatment and hepatitis $\mathrm{C}$ testing

Australian Aboriginals make up approximately 2\% of the Australian population, yet constitute $15 \%$ of the national prison population (Australian Bureau of Statistics, 1998, 2002). In New South Wales (NSW) prisons, $19 \%$ of female inmates were of Aboriginal or Torres Strait Islander descent compared to 14\% of male inmates (Corben, 2001).

Injecting drug users (IDUs) are also overrepresented in prison populations. A study of prison entrants in the state of Victoria found that $46 \%$ of the sample reported a history of injecting drug use, many of whom injected drugs while in prison (Crofts et al., 1995). The NSW Inmate Health Survey found that $32 \%$ of females and $21 \%$ of males had injected drugs in prison at some time (Butler, 1997).

Given the unknown parameters of the IDU population, it is difficult to know the prevalence of injecting drug use among Aboriginal and non-Aboriginal groups. The National Drug Strategy Household Survey found that the prevalence of heroin, cocaine and amphetamine use was similar among Aboriginal and non-Aboriginal populations (Commonwealth Department of Health and Aged Care, 1994), though household surveys are likely to underestimate illicit drug use (Hall, Ross, Lynskey, Law, \& Degenhardt, 2000). Furthermore, the extent of injecting drug use is likely to differ between jurisdictions and communities. One study reported significantly different levels of lifetime heroin use among Ab- 
original communities living in two small urban communities in NSW (12\% vs. 1\%) (Perkins et al., 1994). Aggregated lifetime prevalence of heroin use for the two communities was higher in the Aboriginal population when compared to the general population (6\% and 2\%) (Perkins et al., 1994).

In the National needle and syringe program survey, 5\% of the sample were Aboriginal, further indicating that Aboriginal people are overrepresented among IDU populations (MacDonald et al., 1997). This trend has been even more evident in Sydney: in the Australian Study of HIV and Injecting Drug Use, 13\% of the Sydney sample were Aboriginal, compared to $5 \%$ of the national sample, despite similar recruitment methods (Loxley, Carruthers, \& Bevan, 1995; Rutter, Dolan, \& Wodak, 1996).

Despite a burgeoning body of literature on alcohol and other drug problems among Aboriginal people (for a review see Gracey, 1998), a review of Australian illicit drug research found that there has been little research into Aboriginal injecting drug use (Hando, Hall, Rutter, \& Dolan, 1998). With secondary analyses of existing databases, the current study examined differences between Aboriginal and non-Aboriginal IDUs in terms of gender, prison history, hepatitis $\mathrm{C}$ virus antibody (HCV) testing and drug treatment history.

\section{METHODS}

Studies completed by the National Drug and Alcohol Research Centre (NDARC) since 1997, which targeted IDUs and contained information on Aboriginal and Torres Straight Islander status, were selected. Data for three cross-sectional studies of IDUs recruited in Sydney were available for review: The Illicit Drug Reporting System (IDRS), the Australian Prevalence and Estimate of Treatment Study (APET) and the Australian Blood-borne virus Risk and Injecting Drug Use Study (ABRIDUS). The IDRS involved a cross-sectional study repeated over four years (1997-2000). These studies were aggregated into one data set. APET data were collected from October 2000 to March 2001 and ABRIDUS data were collected in 1999.

All studies targeted similar populations and used similar entry criteria. Participants were either current IDUs (any drug), heroin users or on a methadone maintenance program. Aboriginal IDUs were not specifically targeted and participation was voluntary. 
In each study participants were recruited through a variety of methods, including needle and syringe programs and methadone clinics, or via street intercept and snowballing (word of mouth). Interviews were conducted face-to-face by trained interviewers using structured questionnaires. Participants were reimbursed $\$ 20$ or $\$ 30$ for travel expenses.

All studies collected information on demographics, main drug used, needle and syringe sharing and prison history. APET and ABRIDUS collected information on self-reported HCV status and drug treatment history. APET also collected information on HCV testing.

\section{RESULTS}

Aboriginal people were overrepresented in all three studies, constituting 15-19\% of the samples (Table 1). Characteristics of Aboriginal and non-Aboriginal IDU are shown in Table 2. There were more female Aboriginal IDU than non-Aboriginal IDU in APET $\left(56 \%\right.$ vs. $33 \%, \chi^{2}=$ $12.62,1 d f, \mathrm{p}<0.001)$.

Lifetime prevalence of incarceration was higher in the Aboriginal sample than the non-Aboriginal sample in the IDRS $\left(68 \%\right.$ vs. $49 \%, \chi^{2}=$ $13.72,1 d f, \mathrm{p}<0.001)$.

More Aboriginal IDUs reported heroin as their main drug than non-Aboriginal IDUs, in APET ( $87 \%$ vs. $76 \%, \chi^{2}=4.32,1 d f$, $\left.\mathrm{p}<0.05\right)$. Similar proportions of Aboriginal and non-Aboriginal IDUs reported using a needle or syringe after another person in the last month. Aboriginal and non-Aboriginal IDUs were similar in all other areas investigated (Table 2).

\section{Female IDUs}

There were 441 female IDUs in the three studies, representing $24 \%$ of participants in all studies. More Aboriginal females reported a history of incarceration than non-Aboriginal females in the IDRS (68\% vs.

TABLE 1. Percent of Aboriginal IDU in Each Study

\begin{tabular}{lccc}
\hline Study & Year of Data Collection & $\mathrm{n}$ & \% Aboriginal \\
\hline APET & $2000-2001$ & 399 & 17 \\
IDRS & $1997-2000$ & 636 & 19 \\
ABRIDUS & 1999 & 150 & 15 \\
\hline
\end{tabular}


TABLE 2. Characteristics of Aboriginal and Non-Aboriginal IDU

\begin{tabular}{|c|c|c|}
\hline Variable & Aboriginal & Non-Aboriginal \\
\hline \multicolumn{3}{|l|}{ Mean Age (SD) } \\
\hline APET & $33(6.7)$ & $31(8.2)$ \\
\hline IDRS & $30(7.1)$ & $29(7.9)$ \\
\hline ABRIDUS & $29(7.9)$ & $30(7.8)$ \\
\hline \multicolumn{3}{|l|}{$\%$ Female } \\
\hline APET* $^{*}$ & 59 & 33 \\
\hline IDRS & 39 & 35 \\
\hline ABRIDUS & 45 & 38 \\
\hline \multicolumn{3}{|c|}{$\%$ Ever been in prison } \\
\hline APET & 54 & 39 \\
\hline IDRS* $^{*}$ & 68 & 49 \\
\hline ABRIDUS & 68 & 51 \\
\hline \multicolumn{3}{|c|}{$\begin{array}{l}\% \text { Used a syringe after another } \\
\text { person in past month }\end{array}$} \\
\hline APET & 7 & 9 \\
\hline IDRS & 10 & 18 \\
\hline ABRIDUS & 24 & 26 \\
\hline \multicolumn{3}{|c|}{$\%$ HCV positive (self reported) } \\
\hline APET & 59 & 59 \\
\hline ABRIDUS & 67 & 64 \\
\hline \multicolumn{3}{|c|}{$\%$ Main drug heroin } \\
\hline $\mathrm{APET}^{\star *}$ & 87 & 76 \\
\hline IDRS & 85 & 78 \\
\hline ABRIDUS & 77 & 69 \\
\hline \multicolumn{3}{|c|}{$\begin{array}{l}\% \text { History of treatment for heroin } \\
\text { dependence }\end{array}$} \\
\hline APET & 59 & 59 \\
\hline ABRIDUS & 67 & 64 \\
\hline \multicolumn{3}{|c|}{$\begin{array}{l}\% \text { Ever experienced a barrier } \\
\text { to treatment for heroin use }\end{array}$} \\
\hline APET & 38 & 40 \\
\hline
\end{tabular}

${ }^{*} \mathrm{p}<0.001,{ }^{* *} \mathrm{p}<0.05$

$\left.49 \%, \chi^{2}=6.61,1 d f, \mathrm{p}<0.01\right)$ and ABRIDUS (68\% vs. $51 \%$, Fisher's exact test, $\mathrm{p}<0.01$ ).

There were no significant differences in terms of self-reported HCV status between the Aboriginal and non-Aboriginal females or in receiving pre- and post-test counselling. However, Aboriginal females were significantly more likely to report a longer period of time since their last HCV test (45 vs. 25 weeks, $\mathrm{t}_{137}=2.58, \mathrm{p}<0.01$ ). 
In APET more Aboriginal females reported heroin as their main drug compared to non-Aboriginal females $(90 \%$ vs. $72 \%$, Fisher's exact test, $\mathrm{p}<$ $.05)$. Similar proportions of Aboriginal and non-Aboriginal females reported ever having been in drug treatment in both APET ( $82 \%$ and $87 \%$, respectively) and ABRIDUS (80\% and 56\%).

\section{DISCUSSION}

To date there has been little research into injecting drug use among Aboriginal people and little is currently known about this group (Hando et al., 1998). This study, however, has found that Aboriginal people were overrepresented among samples of IDUs in Sydney. Compared to non-Aboriginal IDUs, Aboriginal IDUs were more likely to have been imprisoned. The study has also found that Aboriginal females were overrepresented in samples of IDUs relative to non-Aboriginal females, and that these Aboriginal females were significantly more likely to have a history of incarceration. Both of these factors suggest that Aboriginal IDUs and their communities are at a double disadvantage in terms of blood-borne viral risk.

The overrepresentation of Aboriginal people in Australian prisons has been well documented, as has the overrepresentation of IDUs (Butler et al., 1997; Crofts et al., 1995; Royal Commission into Aboriginal Deaths in Custody, 1991). The prevalence of HCV among Australian prisoners is also high (Butler et al., 1997; Crofts et al., 1995) and despite limited research, transmission is also likely to be high (Dolan, 2001). Aboriginal people who inject drugs were more likely to report a history of incarceration than their non-Aboriginal peers, placing them and their communities at higher risk of blood-borne viral infections than other IDUs.

Some reasons given for the elevated levels of incarceration of Aboriginal people generally include issues around racism, colonisation, and the dispossession of land and culture oppression (Lincoln \& Wilson, 1994). The added problems of dependency and the pressure and stigma of illicit drug use may further compound the problem.

Females typically account for approximately a third of the IDU population (Loxley et al., 1995; MacDonald et al., 1997). Yet, this study found that Aboriginal females constitute closer to 50\% of Aboriginal IDUs and that they were more likely to have been incarcerated than non-Aboriginal female IDUs. Females who inject drugs are disadvantaged in a range of areas, including syringe sharing and treatment op- 
tions (Whynot, 1998). The prevalence of HCV is also higher among female prisoners compared to male prisoners (Butler et al., 1997; Crofts et al., 1995). These three factors taken together indicate greater HCV risk for Aboriginal female IDUs compared to non-Aboriginal female IDUs.

Aboriginal females were less likely to have reported being recently tested for $\mathrm{HCV}$ than the non-Aboriginal females, indicating that HCV may be higher than reported. As demonstrated with HIV, pre- and post-test counselling can reduce risk behaviour (Gibson, McCusker, \& Chesney, 1998). That large proportions of IDUs had not received counselling (or do not remember anything of the process) is of concern and has implications in terms of the prevention of blood-borne viral transmission and requires further investigation.

There are a number of limitations of this study. The data presented here were from three different studies with different aims and therefore instruments. However, all three studies were conducted by the same Centre and similar methodologies were employed. The small numbers of participants in each study may have compromised statistical power and therefore the number of firm conclusions that can be made.

Nonetheless, the data from this study have suggested that Aboriginal people were overrepresented among IDUs, particularly females, and are therefore at increased risk of $\mathrm{HCV}$ and other blood-borne infections. Given the high prevalence of incarceration reported by Aboriginal IDUs, the prison setting provides an opportunity to promote drug treatment and blood-borne virus testing. However, more needs to be done to reduce the numbers of both Aboriginal people and IDUs entering prison.

\section{REFERENCES}

Australian Bureau of Statistics (1998). Australian Social Trends 1998 (Cat no. 4102.0). Canberra: Commonwealth of Australia.

Australian Bureau of Statistics (2002). Prisoners in Australia (Cat no. 4517.0). Canberra: Commonwealth of Australia.

Butler, T. (1997). Preliminary Findings from the Inmate Health Survey of the Inmate Population in the New South Wales Correctional System. Sydney: Corrections Health Service.

Butler, T. G., Dolan, K. A., Ferson, M. J., McGuinness, L. M., Brown, P. R., \& Robertson, P. W. (1997). Hepatitis B and C in New South Wales prisons: Prevalence and risk factors. Medical Journal of Australia, 166, 127-130.

Commonwealth Department of Health and Aged Care (1994). National Drug Strategy Household Survey: Urban Aboriginal and Torres Strait Islander Peoples Supplement 1994. Canberra: AGPS. 
Corben, S. (2001). NSW Inmate Census 2000: Summary of Characteristics (Statistical Publication No. 22). Sydney: NSW Department of Corrective Services.

Crofts, N., Stewart, T., Hearne, P., Ping, X. Y., Breshkin, A. M., \& Locarnini, S. A. (1995). Spread of bloodborne viruses among Australian prison entrants. British Medical Journal, 310, 285-288.

Dolan, K. A. (2001). Can Hepatitis C transmission be reduced in Australian prisons? Medical Journal of Australia, 174, 378-379.

Gibson, D. R., McCusker, J., \& Chesney, M. (1998). Effectiveness of psychosocial interventions in preventing HIV risk behaviour in injecting drug users. AIDS, 12, 919-929.

Gracey, M. (1998). Substance misuse in Aboriginal Australians. Addiction Biology, 3, 29-46.

Hall, W. D., Ross, J. E., Lynskey, M. T., Law, M. G., \& Degenhardt, L. J. (2000). How many dependent heroin users are there in Australia? Medical Journal of Australia, $173,528-531$.

Hando, J., Hall, W., Rutter, S., \& Dolan, K. (1998). An Information Document on the Current State of Research on Illicit Drugs in Australia. Canberra: National Health and Medical Research Council.

Lincoln, R., \& Wilson, P. (1994). Aboriginal offending: Patterns and causes. In D. Chappell \& P. Wilson (Eds.), The Australian Criminal Justice System: The 1990s (pp. 61-86). Sydney: Butterworths.

Loxley, W., Carruthers, S., \& Bevan, J. (1995). In the Same Vein: First Report of the Australian Study of HIV and Injecting Drug Use (ASHIDU). Perth: Curtin University of Technology.

MacDonald, M., Wodak, A. D., Ali, R., Crofts, N., Cunningham, P. H., Dolan, K. A., Kelaher, M., Loxley, W. M., van Beek, I., \& Kaldor, J. M. (1997). HIV prevalence and risk behaviour in needle exchange attenders: A national study. Medical Journal of Australia, 166, 237-240.

Perkins, J. J., Sanson-Fisher, R. W., Blunden, S., Lunnay, D., Redman, S., \& Hensley, M. J. (1994). The prevalence of drug use in urban Aboriginal communities. Addiction, 89, 1319-1331.

Royal Commission into Aboriginal Deaths in Custody (1991). National Report. Canberra: AGPS.

Rutter, S., Dolan, K., \& Wodak, A. (1996). Sex, Drugs and Viruses in Sin City Sydney, 1994 (NDARC Technical Report No. 37). Sydney: National Drug and Alcohol Research Centre, University of New South Wales.

Whynot, E. (1998). Women who use injection drugs: The social context of risk. Canadian Medical Association Journal, 159, 355-358.

SUBMITTED: $11 / 08 / 02$

ACCEPTED: 02/15/03 